\title{
Penggunaan Peraturan Bupati Untuk Mengatur Harga Tanah Dalam Pengenaan Bea Perolehan Hak Atas Tanah Dan Bangunan
}

\author{
Budi Ispriyarso \\ Fakultas Hukum, Universitas Diponegoro \\ budiispriyarso@ymail.com
}

\begin{abstract}
This study aims to describe the use of regent regulations to regulate land prices in the Imposition of Fees for Acquisition of Land and Building Rights. This research is a normative legal research that uses the regulatory approach. the results showed that the use of District Regulation as a basis for setting land prices in the imposition of BPHTB in Kendal district, was a regulation made for the purpose of legal certainty about land prices, but from the juridical aspects the regent regulation was not based on the delegation of authority in Kendal district regulation. Regulating BPHTB. Then the estimated price of land as regulated in Kendal Regulation No. 10 of 2017 is based on location criteria, namely Settlements, Agricultural Land and Housing). And the estimated price of land which is regulated in Kendal Regulation Number 10 of 2017, functions as a comparison.
\end{abstract}

Keywords: Land Prices. BPHTB, Land Tax.

Abstrak

Penelitian ini bertujuan untuk menguraikan Penggunaan Peraturan Bupati Untuk Mengatur Harga Tanah Dalam Pengenaan Bea Perolehan Hak Atas Tanah Dan Bangunan. Penelitian ini merupakan penelitian hukum normatif yang menggunakan pendekatan peraturan perundang undangan. hasil penelitian menunjukan bahwa Penggunaan Perbup sebagai dasar untuk menetapkan harga tanah dalam pengenaan BPHTB di kabupaten kendal, merupakan peraturan yang dibuat tujuan kepastian hukum tentang harga tanah, namun dari aspek yuridis peraturan bupati tersebut tidak didasarkan pada adanya delegasi kewenangan yang terdapat dalam Perda kabupaten Kendal yang mengatur BPHTB. Kemudian Perkiraan harga tanah yang diatur dalam Perbup Kendal Nomor 10 Tahun 2017 didasarkan pada kriteria lokasi yaitu Pemukiman, Tanah Pertanian dan Perumahan). Dan Perkiraan harga tanah yang diatur Dalam Perbup Kendal Nomor 10 Tahun 2017,berfungsi sebagai pembanding.

Kata Kunci: Harga Tanah. BPHTB, Pajak Tanah. 


\section{A. Pendahuluan}

Bea perolehan Hak Atas Tanah dan Bangunan (BPHTB) adalah pajak yang dikenakan terhadap perolehan hak atas tanah dan bangunan. Dasar hukumnya adalah UU Nomor 21 Th.1997 tentang BPHTB sebagaimana telah diubah dengan UU Nomor 20 Th.2000.

Seiring dengan pelaksanaan otonomi daerah, BPHTB yang sebelumnya dikelola oleh Pemerintah Pusat, berdasarkan Undang-undang Nomor 28 Tahun 2009 tentang Pajak Daerah dan Retribusi Daerah (PDRD ) dilimpahkan menjadi kewenangan Daerah ( Pasal 180 angka 6 UU PDRD). Khusus mengenai BPHTB diatur dalam Pasal 85 s/d Ps1 93. Mulai 1 Januari 2011, BPHTB telah resmi menjadi pajak daerah .

UU Nomor 28 Tahun 2009 menggantikan UU Nomor 34 Tahun 2000. Perbedaan mendasar kedua undang-undang tersebut adalah UU Nomor 28 Tahun 2009 sifatnya limitatif sedangkan UU Nomor 34 Tahun 2000 sifatnya enumeratif.

Dalam rangka menindaklanjuti dari UU Nomor Nomor 28 tahun 2009 tersebut, maka daerah kabupaten/kota mempersiapkan berbagai instrumen yuridis untuk melaksanakan pemungutan BPHTB sebagai pajak daerah, tidak terkecuali pemerintah Kabupaten Kendal. Pemkab kendal dalam rangka "pendaerahan" BPHTB telah mengeluarkan perda Nomor 11 Tahun 2011 tentang Pajak Daerah (khususnya tentang BPHTB diatur dalam Bab XIII). Selanjutnya untuk melaksanakan perda tersebut, Bupati Kendal mengeluarkan Perbup. Nomor 50 tahun 2011 tentang sistem dan prosedur pemungutan BPHTB Kabupaten Kendal . Dalam perkembangannya, Bupati Kendal dalam rangka pemungutan BPHTB tersebut mengeluarkan Perbup.Nomor 10 Tahun 2017 tentang Perkiraan harga tanah dalam pengenaan BPHTB di Kabupaten Kendal.

Langkah Bupati Kendal mengeluarkan perbup Nomor 10 Tahun 2017 merupakan keberanian pejabat / administrasi negara untuk mengambil suatu tindakan dalam rangka mengatasi permasalahan dalam pelaksanaan pemungutan BPHTB di Kabupaten Kendal demi kepastian hukum sebagai dasar verifikasi /validasi dalam pemungutan BPHTB. Hal yang perlu dicermati mengenai hal tersebut adalah dari aspek yuridis apakah tindakan bupati Kendal mengeluarkan perbup tersebut merupakan hal yang tepat ,apa yang menjadi dasar kewenangan bupati mengeluarkan Perbup tersebut sedangkan perda 
tentang pajak daerah yang mengatur pajak daerah termasuk didalamnya BPHTB tidak memerintahkan untuk membuat perbup. tentang perkiraan harga tanah dalam pengenaan BPHTB (tidak ada delegated legislation ).

\section{Permasalahan :}

Berdasarkan uraian di atas maka permasalahan yang dapat dirumuskan berkaitan dengan Perbup Kendal Nomor 10 Tahun 2017 adalah sebagai berikut : 1). Ditinjau dari aspek yuridis, apakah tepat penggunaan "Perbup" untuk mengatur perkiraan harga tanah dalam pengenaan BPHTB di kabupaten Kendal ? 2). Apa yang dijadikan dasar penentuan perkiraan harga tanah yang diatur dalam Perbup Kendal tersebut ? 3). Apakah tepat bahwa perkiraan harga tanah yang ada dalam Perbup tersebut sebagai "Pembanding".

\section{B. Pembahasan}

\section{Penggunaan "Perbup" untuk mengatur perkiraan harga tanah dan bangunan}

Catatan awal yang menjadi kajian yuridis dalam tulisan ini khususnya dari dari aspek yuridis,adalah apakah penggunaan "Perbup" untuk mengatur perkiraan harga tanah dan bangunan di Kabupaten Kendal merupakan hal yang tepat. Hal ini kemungkinan ada yang mengkritisi bahwa akibat dikeluarkannya perbup tersebut berpotensi menyebabkan antara lain BPHTB menjadi lebih tinggi. Hal ini juga menyangkut pungutan pemerintah terhadap rakyatnya, apakah tidak sebaiknya diatur dalam perda, karena seperti yang diatur dalam Pasal 23 A UUD NRI 1945 sebagai dasar pemungutan pajak di Indonesia disebutkan bahwa pajak dan pungutan lain yang sifatnya memaksa untuk keperluan negara diatur berdasarkan undang-undang. Pemungutan pajak harus dengan undang-undang berarti harus dengan persetujuan rakyat.

Berkaitan dengan hal di atas, dalam pemungutan BPHTB, pada awalnya ketika menjadi pajak pusat dilakukan berdasarkan UU ( UU Nomor 21 Tahun 2017 sebagaimana diubah dengan UU Nomor 20 Tahun 2000). Kemudian setelah menjadi pajak daerah sejak dikeluarkannya UU Nomor 28 tahun 2009 tentang Pajak Daerah dan Retribusi Daerah, pemerintah daerah melakukan pemungutan BPHTB berdasarkan perda dengan mengacu juga ketentuan-ketentuan yang terdapat dalam UU Nomor 28 Tahun 2009. Dalam rangka menindaklanjuti ketentuan-ketentuan itu dalam perda , masing- 
masing pemerintah daerah ( Pemkab/ Pemkot) mengeluarkan peraturan bupati atau peraturan walikota.

Pemerintah Kabupaten Kendal seperti daerah-daerah lainnya, dalam melakukan pemungutan BPHTB juga dilakukan seperti tersebut di atas, yaitu dengan mengeluarkan perda dan selanjutnya membuat perbup. Ada 2 (dua) perbup berkaitan dengan pelaksanaan perda pemkab Kendal Nomor 11 Tahun 2011 tentang pajak Daerah yaitu Perbup. Nomor 50 tahun 2011 tentang sistem dan prosedur pemungutan BPHTB Kabupaten Kendal dan Perbup.Nomor 10 Tahun 2017 tentang Perkiraan harga tanah dalam pengenaan BPHTB di Kabupaten Kendal.

Peraturan Bupati dikeluarkan tentunya antara lain dalam rangka pelaksanaan ketentuan yang terdapat dalam peraturan di atasnya antara lain adalah peraturan daerah. Apabila dicermati terhadap Perbup.Kendal Nomor 10 tahun 2017, ternyata dalam "pertimbangan" tidak terdapat pasal-pasal dalam perda Kabupaten Kendal Nomor 11 Tahun 2011 yang dijadikan sebagai pertimbangan dikeluarkannya perbup. Hal ini berbeda dengan perbup Kendal sebelumnya yaitu perbup Nomor 50 Tahun 2011 tentang Sistem dan Prosedur Pemungutan BPHTB Kendal, yang menyebutkan bahwa perbup ini dikeluarkan dalam rangka pelaksanaan ketentuan Pasal 77 ayat (2), Pasal 87 ayat (6), Pasal 92 ayat (2), Pasal 93 ayat(3), Pasal 101 ayat (3) Perda Kabupaten Kendal Nomor 11 Tahun 2011 tentang Pajak daerah (Hal ini secara tegas disebutkan dalam "Pertimbangan").

Kedua perbup. tersebut mempunyai perbedaan yang cukup mendasar, perbup. Nomor 50 Tahun 2011 , dasar dikeluarkannya perbup tersebut adalah untuk melaksanakan ketentuan perda yang dengan tegas diperintahkan pasal-pasal dalam perda tersebut (terdapat delegasi kewenangan). Sedangkan dalam perbup.Nomor 10 Tahun 2017, tidak mengacu pada adanya perintah yang terdapat dalam perda Kabupaten Kendal tentang Pajak Daerah. Dalam perbup.Nomor 10 Tahun 2017, perda Kabupaten Kendal Nomor 11 Tahun 2011 disebutkan di bagian "Mengingat" angka 15.

Tindakan Bupati Kendal mengeluarkan perbup Nomor 10 Tahun 2017 merupakan langkah yang cukup berani, karena dalam perda tidak ada perintah untuk mengeluarkan aturan/perbup tentang perkiraan harga tanah dalam pengenaan BPHTB atas tanah dan Bangunan di kabupaten Kendal. 
Pertimbangan yang dijadikan alasan dikeluarkannya perbup No.10 tahun 2017 sebagaimana yang dicantumkan dalam "Pertimbangan" adalah untuk mewujudkan obyektifitas dalam melaksanakan penelitian Surat Setoran Pajak Daerah BPHTB (SSPDBPHTB) sebagai acuan pertimbangan penilaian kewajaran harga pasar dalam pengenaan BPHTB dengan maksud sebagai pembanding dalam penelitian SSPD BPHTB, dilakukan berdasarkan pada kriteria lokasi, perkiraan harga tanah pemukiman, perkiraan tanah pertanian dan perkiraan harga tanah perumahan.

Apabila dicermati tentang hal tersebut di atas, di satu sisi maka menurut penulis dari aspek yuridis khususnya dari aspek proses pendelegasian wewenang legislasi terdapat ketidakjelasan karena tidak terdapat satu pasalpun yang "memerintahkan" untuk membuat perbup yang berkaitan dengan perkiraan harga tanah. Perbup.seharusnya mengacu pada ketentuan/peraturan yang ada di atasnya (dalam hal ini adalah perda) sebagai pelaksanaan perda. Namun demikian di sisi lain, ada hal lain yang perlu diperhatikan bahwa dikeluarkan perbup. tersebut adalah untuk mengatasi ketidakpastian hukum tentang harga tanah sehingga diperlukan regulasi/ payung hukum untuk kepastian harga tanah .

\section{Penentuan Perkiraan Harga Tanah dalam Perbup Nomor 11 Tahun 2017}

Mengenai perkiraan harga tanah sebagaimana yang tersebut dalam Pasal 2 ayat

(2) Perbup Nomor 11 Tahun 2017, dilakukan berdasarkan pada kriteria lokasi :

a. Pemukiman;

b. Tanah Pertanian;

c. Perumahan

Pertanyaanya adalah apakah dalam penentuan perkiraan harga tanah ini telah dilakukan studi komparatif dengan pemkab/pemkot lainnya atau dengan instansi lainnya (BPN). Sebagaimana diketahui bahwa saat ini BPN telah mempunyai perkiraan harga tanah dengan Zone Nilai Tanah (untuk kepentingan PNBP). Saat ini terdapat keanekaragaman dalam penentuan harga tanah, antara lain adalah :

1. Harga tanah berdasarkan NJOP ( untuk keperluan PBB)

2. Harga tanah berdasarkan ZNT - BPN ( untuk keperluan PNBP )

3. Harga tanah berdasarkan harga pasaran. 
4. Harga Tanah berdasarkan Perbup Nomor 11 Tahun 2017 (untuk keperluan BPHTB)

Hendaknya dalam penentuan perkiraan harga tanah terdapat sinkronisasi dengan instansi lain, sehingga terdapat keseragaman, keadilan dan kepastian hukum, tidak menimbulkan kebingungan/keresahan masyarakat. Hal ini terdapat kemungkinan dengan obyek yang sama, terdapat perkiraan harga tanah yang berbeda, oleh pemkot, BPN, harga pasaran, harga berdasarkan NJOP.

Disamping itu dalam penentuan perkiraan tanah harus sesuai dengan asas kecermatan, sehingga diperoleh hasil yang sesuai yang diharapkan ( sesuai atau mendekati harga pasaran yang sebenarnya.)

\section{Perkiraan tanah dipergunakan sebagai "Pembanding" dalam penelitian SSPD- PHTB}

Perda Kabupaten Kendal Nomor 11 tahun 2011 khususnya Pasal 71 menentukan bahwa dasar pengenaaan BPHTB adalah Nilai Perolehan Obyek Pajak (NPOP). NPOP tersebut adalah harga transaksi atau nilai pasar. NPOP untuk Jual beli menggunakan harga transaksi.

Berdasarkan ketentuan perda tersebut, maka secara yuridis dalam pembayaran BPHTB karena jual beli harus berdasarkan harga transaksi. Namun dalam prakteknya, ada diantara wajib pajak yang berusaha merendahkan BPHTB nya dengan cara merendahkan harga transaksinya (tidak sesuai dengan harga sebenarnya). Hal ini tentunya akan mengakibatkan berkurangnya penerimaan daerah dari sektor BPHTB. Oleh karena itulah maka untuk mengantisipasi hal tersebut, setelah BPHTB menjadi pajak daerah terdapat validasi dan verifikasi untuk mencegah kecurangan tersebut. Adanya Perbup Kendal Nomor 10 tahun 2017 tentang perkiraan harga tanah untuk kepentingan hal tersebut.

Perkiraan harga tanah dalam perbup tersebut dijelaskan sebagai "Pembanding" dalam penelitian SSPD BPHTB. Namun pengertian "pembanding” ini tidak ada penjelasan lebih lanjut. Sebaiknya seperti perbup-perbup lainnya, perbup Nomor 10 tahun 2017 dilengkapi dengan Penjelasan. Kemungkinan yang dimaksud sebagai "pembanding" adalah perbandingan harga transaksi jual beli yang disampaikan wajib pajak dengan harga perkiraan harga tanah sebagaimana yang 
terdapat dalam lampiran perbup tersebut.Jika harga transaksi sesuai dengan harga yang tercantum dalam lampiran perbup, maka tidak akan dilakukan penagihan.

'Prinsipnya perbup tidak boleh bertentangan dengan perda atau peraturan yang di atasnya. Secara yuridis kalau perda sudah menetapkan bahwa NPOP jual beli didasarkan pada harga transaksi maka perbup sebagai peraturan pelaksanaanya harus sejalan dengan ketentuan perda tersebut, tidak boleh dengan harga lainnya misalnya harga penetapan dari pemkab/pemkot. Namun sekali lagi, karena dalam prakteknya kemungkinan terjadi "harga transaksi”yang tidak sesuai dengan sebenarnya, maka seperti pemerintah kota/kabupaten lainnya, pemkab kendal juga melakukan validasi dan verifikasi. Perbedaannya pemkab Kendal sudah mengeluarkan perbup. yang mengatur perkiraan harga tanah dalam pengenaan BPHTB. Prinsipnya NPOP untuk jual beli didasarkan pada harga transaksi (untuk jual beli), namun apabila dianggap tidak sesuai dengan perkiraan harga tanah dalam perbup maka akan dilakukan penagihan. Perkiraan harga tanah dalam perbup difungsikan sebagai "Pembanding". Namun demikian fungsi pembanding ini harus dilakukan dengan penuh kecermatan, jangan sampai harganya terlalu tinggi dibandingkan harga pasaran.

\section{Kesimpulan}

Berdasarkan uraian di atas dapat disimpulkan hal-hal sebagai berikut :

1. Penggunaan Perbup sebagai dasar untuk menetapkan harga tanah dalam pengenaan BPHTB di kabupaten kendal, merupakan peraturan yang dibuat tujuan kepastian hukum tentang harga tanah, namun dari aspek yuridis peraturan bupati tersebut tidak didasarkan pada adanya delegasi kewenangan yang terdapat dalam Perda kabupaten Kendal yang mengatur BPHTB.

2. Perkiraan harga tanah yang diatur dalam Perbup Kendal Nomor 10 Tahun 2017 didasarkan pada kriteria lokasi yaitu Pemukiman, Tanah Pertanian dan Perumahan).

3. Perkiraan harga tanah yang diatur Dalam Perbup Kendal Nomor 10 Tahun 2017,berfungsi sebagai pembanding. 


\section{Saran}

Hendaknya terdapat sinkronisasi peraturan yang berkaitan dengan harga tanah untuk kepastian hukum dan keadilan. Selama ini terdapat beberapa harga tanah yang berbeda antara satu dan lainnya, misalnya harga tanah oleh BPN, harga tanah berdasarkan harga pasaran, harga tanah berdasarkan Nilai Jual Obyek Pajak dan harga tanah yang diatur oleh perbup.

\section{Daftar Pustaka :}

Anggara Sahya, Hukum Administrasi perpajakan, Bandung: Pustaka setia, 2016.

Siulaiman, King Faisal, dialektika Pengujian Peraturan Daerah Pasca Otonomi Daerah, Jogjakarta : Pustaka Pelajar,2014.

Tyesta, Lita ALW, Pembentukan Peraturan Perundang-undangan, Yogyakarta : Genta Press, 2012.

Harisusanto, Sri Nur, Tindakan diskresi pemerintah dan implikasinya terhadap Penyalahgunaan Wewenang, Seminar Hasil Penelitian Disertasi, PDIH Undip, 2016.

Undang-Undang Nomor 21 Tahun 2000 tentang BPHTB

Undang-Undang Nomor 28 tahun 2009 tentang pajak Daerah dan Retribusi daerah

Peraturan daerah Kabupaten Kendal Tahun 2011 tentang Pajak Daerah

Peraturan Bupati Kendal Nomor 50 tahun 2011 tentang sistem dan Prosedur Pemungutan BPHTB Kabupaten Kendal

Peraturan Bupati Kendal Nomor 10 tahun 2017 tentang Perkiraan Harga Tanah Dalam pengenaan BPHTB di Kabupaten Kendal 